The Atlantic Councill promotes constructive U.S. leadership and engagement in international affairs based on the central role of the Atlantic community in meeting the international challenges of the 21st century. The Council embodies a non-partisan network of leaders who aim to bring ideas to power and to give power to ideas by:

- stimulating dialogue and discussion about critical international issues with a view to enriching public debate and promoting consensus on appropriate responses in the Administration, the Congress, the corporate and nonprofit sectors, and the media in the United States and among leaders in Europe, Asia, Africa and the Americas;

- conducting educational and exchange programs for successor generations of U.S. leaders so that they will come to value U.S. international engagement and have the knowledge and understanding necessary to develop effective policies.

Through its diverse networks, the Council builds broad constituencies to support constructive U.S. leadership and policies. Its program offices publish informational analyses, convene conferences among current and/or future leaders, and contribute to the public debate in order to integrate the views of knowledgeable individuals from a wide variety of backgrounds, interests, and experiences. The South Asia Center is the Atlantic Council's focal point for work on Afghanistan, Pakistan, India, Bangladesh, Sri Lanka, Nepal and Bhutan as well as on relations between these countries and China, Central Asia, Iran, the Arab world, Europe and the U.S. As part of the Council's Asia program, the Center seeks to foster partnerships with key institutions in the region to establish itself as a forum for dialogue between decision makers in South Asia, the U.S. and NATO. These deliberations cover internal and external security, governance, trade, economic development, education and other issues. Working within the region itself, rather than in Washington alone, creates greater local ownership of results. 


\section{Pakistan in the Danger Zone A Tenuous U.S. - Pakistan Relationship}

Shuja Nawaz, Director, South Asia Center of the Atlantic Council of the United States

June 2010

Production and Dissemination Funded By:

ML Resources, LLC, Washington, DC 


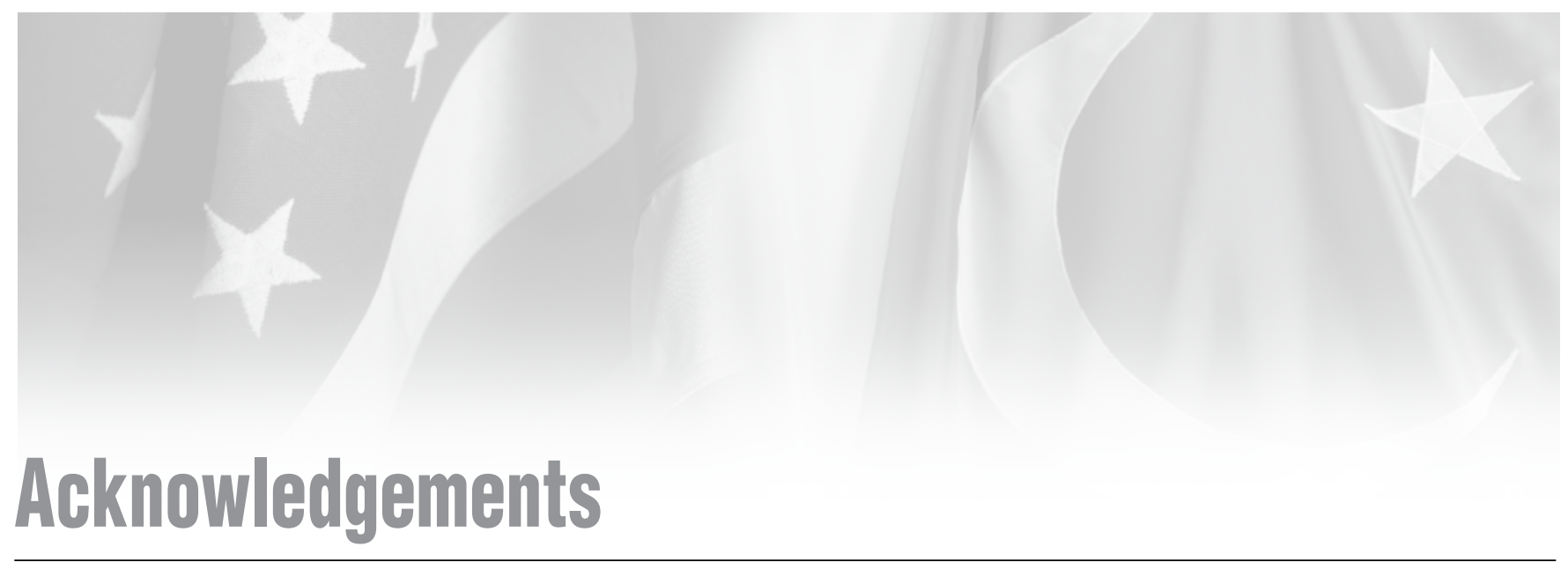

his report was prepared with information, support, and commentary from many people, among them, Sir Hilary Synnott, Shikha Bhatnagar, Ainab Rahman, Jeff Lightfoot, Arnaud de Borchgrave, Jonathan Paris, Shahid Javed Burki, Shahid Yusuf, and staff of the International Monetary Fund. The responsibility for the final product and any errors or omissions is the author's alone. 


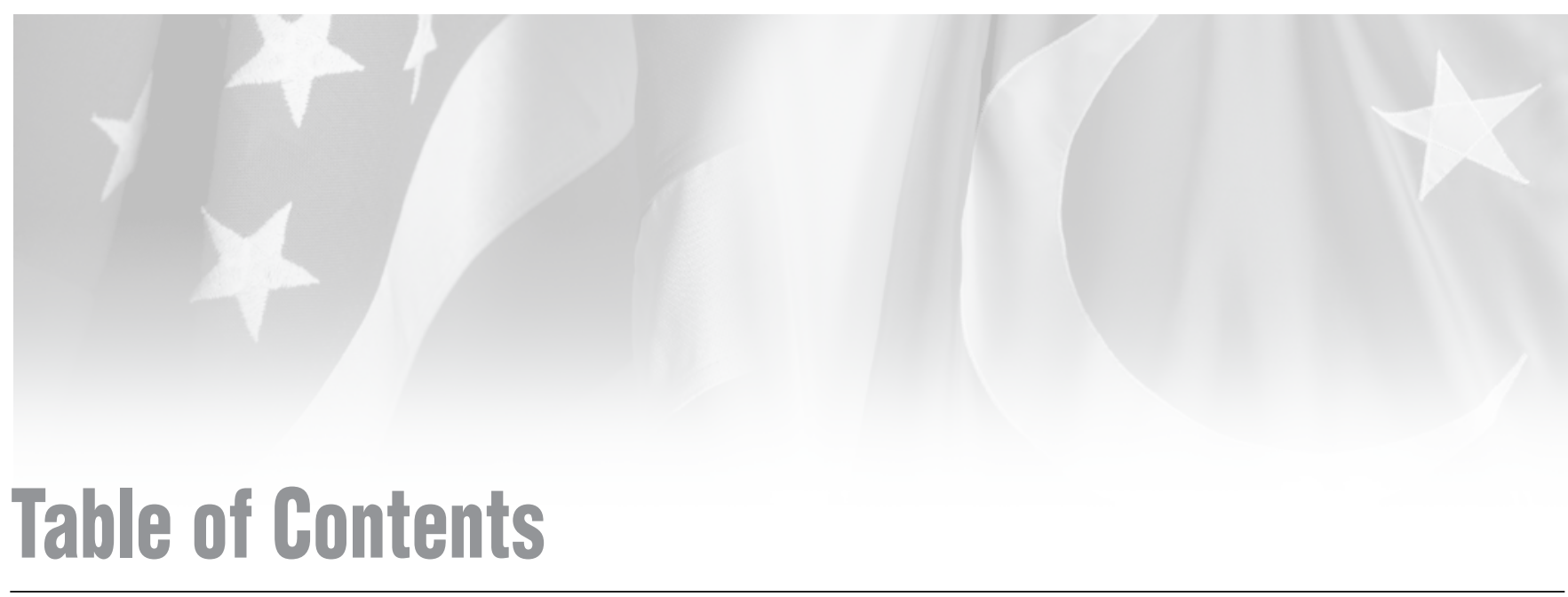

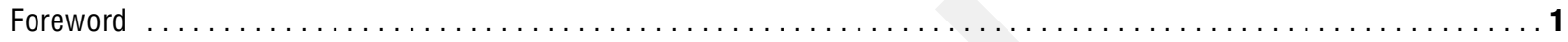

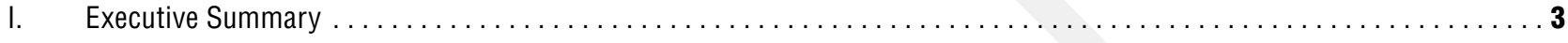

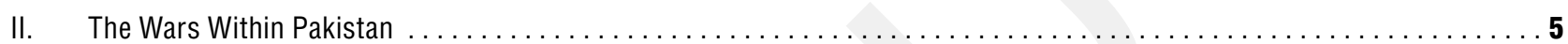

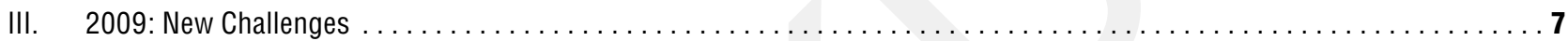

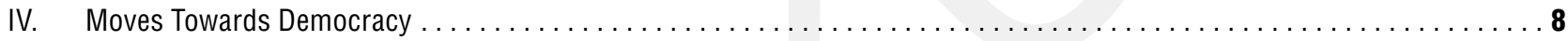

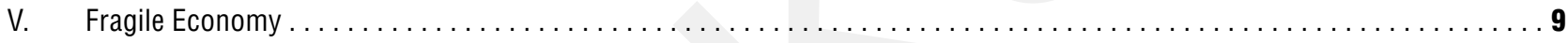

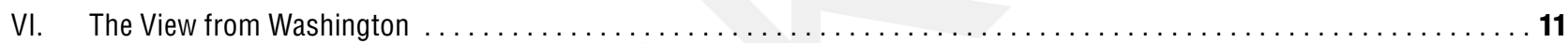

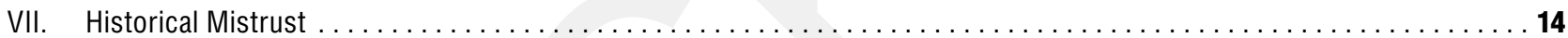

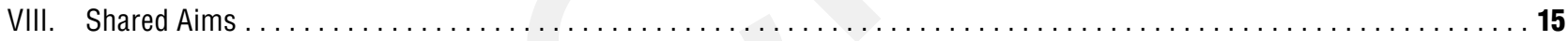

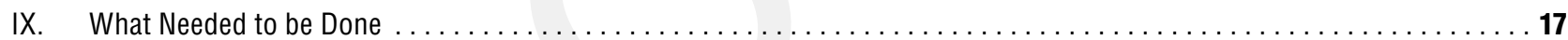

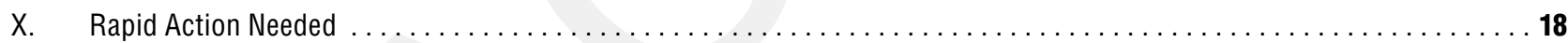

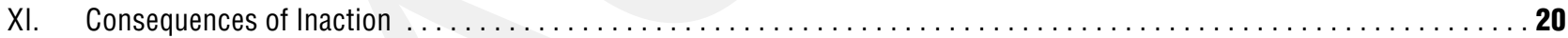


p 


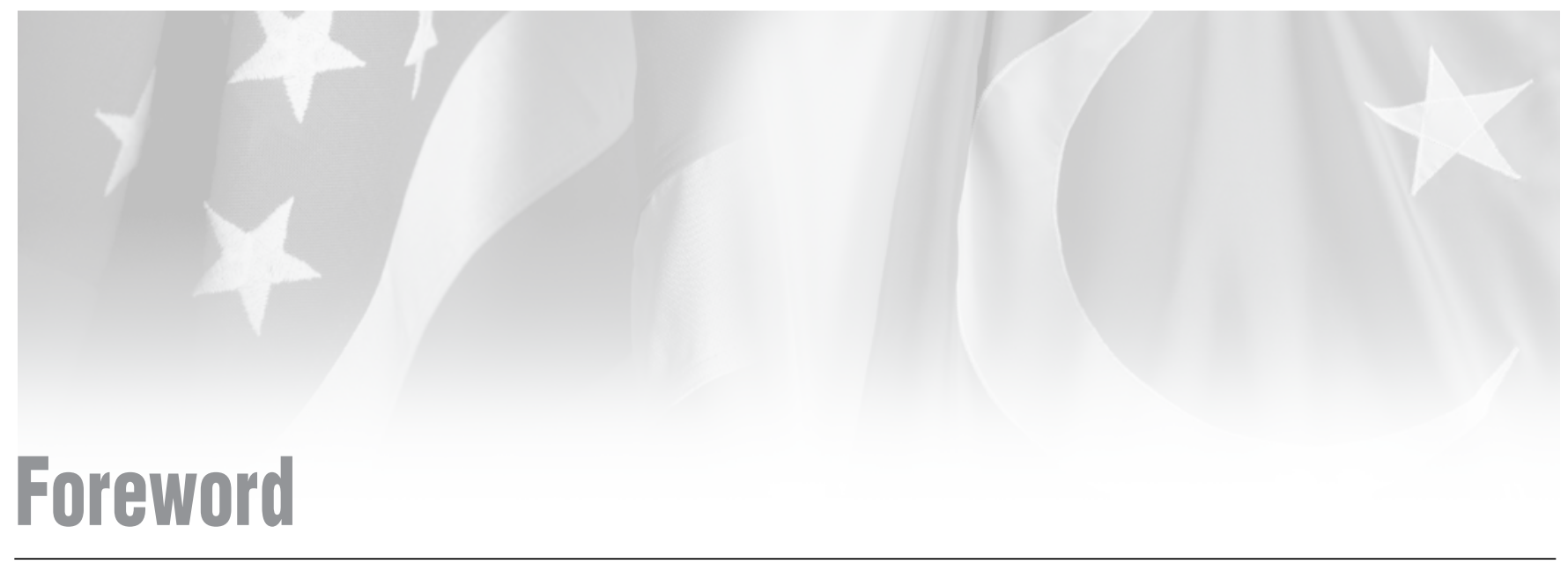

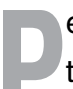
erhaps no bilateral relationship in the world matches that of the United States and Pakistan when it comes to its combustible combination of strategic importance and perilous instability. For that reason, the Atlantic Council has made it a priority to track closely the Obama administration's considerable and often admirable efforts to strengthen U.S.-Pakistani ties - and make prudent policy suggestions when we believe we can help.

Our report of February 2009, Needed: A Comprenhensive U.S. Policy Towards Pakistan', signaled key recommendations for U.S. policymakers on how to achieve a sustainable and productive relationship between the two countries. U.S. officials implemented some of those steps, such as the announcement of a new policy toward the region, the appointment of a Special Representative for Afghanistan and Pakistan, and provision of longer-term aid. However, new U.S. miscues that included public criticism of the military and intelligence services and failure to open up U.S. markets to Pakistani goods, combined with Pakistan's own economic and political turmoil to exacerbate tensions and raise new obstacles to moving forward in a stable and sustainable manner.

Well into President Barack Obama's second year, our South Asia Center director, Shuja Nawaz, argues that U.S.Pakistani relations remain in trouble and require change in how both sides are managing the relationship. He argues that the U.S. is still struggling to define the relationship both in the context of the Afghanistan war and in how it wishes to interact with Pakistan in the broader context of one of the globe's most explosive regions. He writes that Pakistan, for its part, is muddling through in a manner that will not lift it out of the economic and political difficulties that arose out of extended autocratic rule. Cronyism, nepotism, and corruption remain serious challenges to the functioning of government. The government needs to be on a war footing to tackle the insurgency and implement the economic reforms that it has undertaken with help from the International Monetary Fund. This report reflects on the past year's efforts to repair the U.S. - Pakistan relationship and how a new American administration, key pieces of legislation, and shifting Pakistani domestic politics have brought a new dynamic. Rather than wringing his hands over the remaining bilateral problems, Shuja instead outlines ways that the two sides can strengthen a relationship which remains precarious despite a remarkably sustained focus by some of the Obama administration's most senior officials who consider the establishment of a stable, moderate Pakistan a national security priority. As this paper argues, however, the U.S. will achieve best results by helping Pakistan help itself to effectively undermine the militant extremists' influence and activities in the country, and the region.

The release of last year's report on Pakistan coincided with the launch of the South Asia Center at the Atlantic Council. Under Shuja's direction, the South Asia Center has become one of the most important voices on Pakistan's future, on the myriad issues swirling around Afghanistan and on matters of regional stability from the Gulf and South Asia to Central Asia. Our purpose is to "wage peace" in the region by applying the most creative thinking to its challenges through coalescing the best minds and influential actors in the U.S., Europe and across greater South Asia. 
The Council would like to thank the members of the Atlantic Council staff and supporters who contributed to this project. This report also would not have been possible without information and commentary from Sir Hilary Synnott, Shikha Bhatnagar, Ainab Rahman, Jeff Lightfoot, Arnaud de Borchgrave, Jonathan Paris, Shahid Javed Burki, Shahid Yusuf, and staff of the International Monetary Fund. We are grateful to ML Resources, LLC of Washington D.C. for underwriting the production and dissemination of the report.

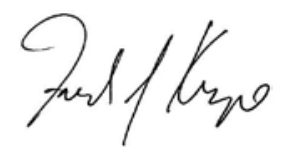

\section{Frederick Kempe}

President and CEO 


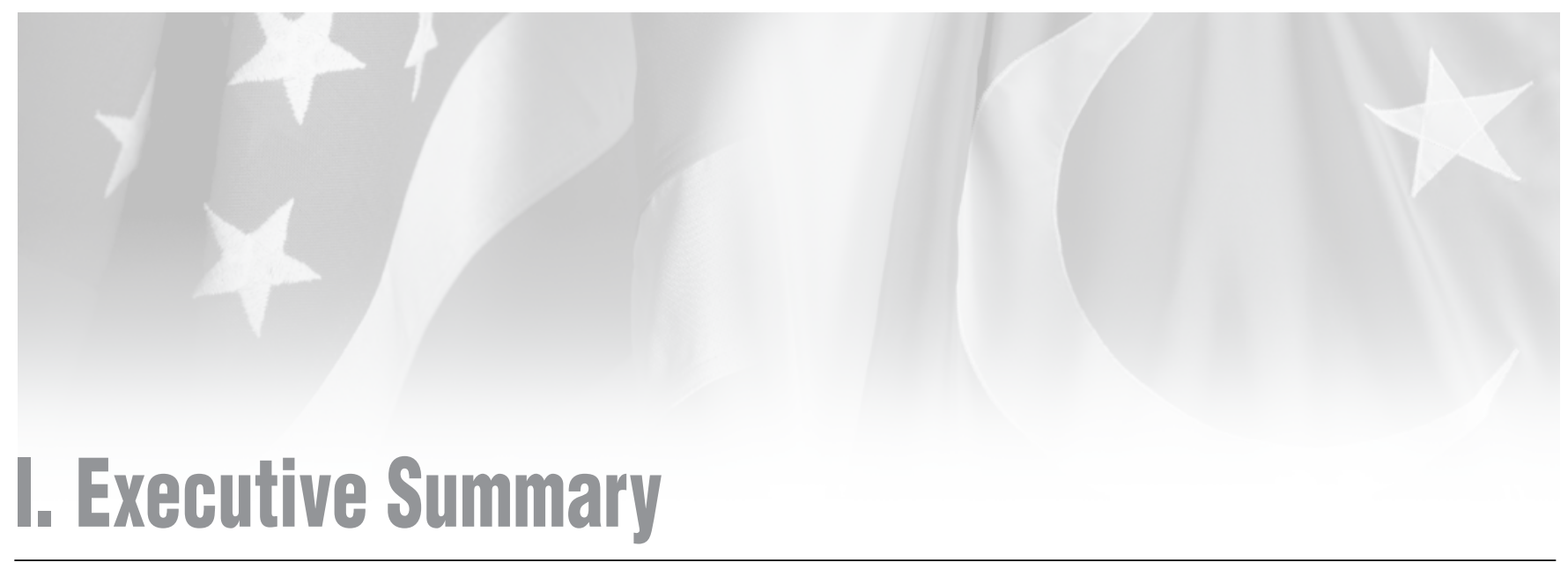

 he Afghanistan war may be lost on the battlefields of Pakistan, where a vicious conflict is now being fought by Pakistan against a homegrown insurgency spawned by the war across its Western frontier. A year after we at the Atlantic Council raised a warning flag about the effects of failure in Afghanistan and the need to meet Pakistan's urgent needs in its existential war against militancy and terrorism, the situation in Pakistan remains on edge. Domestic politics remain in a constant state of flux, with some progress toward a democratic polity overshadowed by periodic upheavals and conflicts between the ruling coalition and the emerging judiciary. The military's actions against the Taliban insurgency appear to have succeeded in dislocating the homegrown terrorists but the necessary civilian effort to complement military action is still not evident. The government does not appear to have the will or the ability to muster support for longer-term reform or sustainable policies. The economy appears to have stabilized somewhat; but security, governance, and energy shortages are major challenges that require strong, consistent, incorruptible leadership rather than political brinkmanship, cronyism, and corruption that remains endemic nationwide. Recent constitutional developments offer a glimmer of hope that may allow the civilian government to restore confidence in its ability to deliver both on the domestic and external front. But the government needs to stop relying on external actors to bail it out and take matters into its own hands.

Unless some game-changing steps are taken by both sides, the U.S.-Pakistan relationship may also be heading into another serious downturn, marked by continuing mistrust and a disconnect between the public posturing and private dialogues. The United States and Pakistan appear to have different objectives while speaking about common goals: while both are fighting terrorism and militancy, the U.S. is looking for a safe military exit out of a stabilized Afghanistan while ensuring that Al Qaeda does not re-emerge. Pakistan seeks to secure its own territory against an active homegrown insurgency, while keeping a wary eye on India to its east. Increasingly, domestic political imperatives seem to be coloring the rhetoric and pushing policy between these two allies. The 2010 midterm elections and a sputtering economy at home feed the U.S. desire to end the Afghan war. An unfinished transition from autocratic presidential rule to a parliamentary system in Pakistan that pitted the civilian president against the military and other political parties in Pakistan has hamstrung Pakistani politics. The European allies in Afghanistan have been missing in action in Pakistan. They have not been able to establish their own relationship with Pakistan in a manner that would engender mutual trust and confidence. They have a minimal presence on the economic development scene in this key country bordering Afghanistan.

Pakistan can begin to turn things around if given the resources and the support it needs from the United States, the international financial institutions, and other friends. But it will also have to take on some major tasks itself, to reorder the political system, rearrange its economic priorities, and truly return power to the people and their representatives. But without tackling these daunting tasks, Pakistan risks political and economic slide. The nexus between security and governance remains critical. Pakistan's civilian government must begin to govern and 
to prosecute the war against militancy on a war footing, not as a part-time activity or a purely military venture outsourced to its army. It must take control of strategy and work with the military to prepare to take over territory that the military wrests back from the insurgency. Now that it has removed some of the constitutional vestiges of the regime of President General Pervez Musharraf, it must also complete the transition from the presidential to a parliamentary system and build on the recently concluded concord between the provinces and between the center and the provinces, under the aegis of the National Finance Commission Award. It must re-order its priorities to revive domestic investment and attract foreign investment. And it must be prepared to plan for effective use of foreign aid. President Asif Ali Zardari has an opportunity to show statesmanship as the constitutional head of state but without the extraordinary powers that he inherited from his military predecessor. In order to do this he will need to build viable longer-term coalitions and change the negative perceptions about himself among the general population.

The United States needs to take some immediate actions to open up its markets to more Pakistani exports by reducing tariffs on Pakistan's exports, as it has done for dozens of other countries across the globe. It must truly roll back the stringent visa restrictions and undue checking of travelers from Pakistan, a move that has further enraged public opinion, especially among the middle class. In other words, the United States must begin to treat Pakistan as an ally so Pakistan can return the favor. For the longer run, it needs to shift to visible and effective heavy infrastructure development and energy investments, and begin investing in the signature projects in the education and health sectors that will not only have longer term impact but also be visible to the general public as a result of U.S. assistance. On the military front, the U.S. needs to provide Pakistan the tools it needs to fight the war against militancy: more helicopters, more protection for its forces; better police and Frontier Corps training, and greater interaction with middle and lower ranking officers, through exchange programs, for example and not just short courses and visits. The flow of military hardware has been spotty at best and certainly not in the volume that would meet or exceed Pakistani expectations. The biggest game changer in terms of public perception will be discussion of an energy-oriented civilian nuclear deal with Pakistan that will treat it on par with neighbor India, but at the same time begin to draw it into the safeguards network of the International Atomic Energy Agency and thereby dissuade it from any recidivist tendencies toward proliferation. At the same time, removal of U.S. pressure against an IranPakistan oil pipeline that could be extended to India would be seen as a positive step toward helping the US' friends in South Asia.

The United States should also use its new status as a strategic partner of both India and Pakistan to bring the two neighbors together to pick up on the resolution of solvable disputes while reducing tensions on issues that may require more time to mature. Providing help in making their common counter terrorism approaches more effective may be one way to build mutual confidence between these two key neighbors. Finally, the United States and its allies can help India and Pakistan see the importance and great economic value of open borders, transit trade, and economic ties between South Asia, Afghanistan, and Central Asia. Governments in the subcontinent need to catch up with their public opinion that favors peace over confrontation in the subcontinent.

2009 was marked by missed opportunities in both Pakistan and the United States: many good intentions were undermined by subsequent actions. A generous, long-term aid bill (Kerry-Lugar) was saddled with "principles" that were read in Pakistan as conditions while the requirement of "waivers" were interpreted as threats similar to past U.S. sanctions. Delays in processing Coalition Support Fund (CSF) reimbursements continued to be the source of unhappiness on both sides. The CSF approach remains flawed and creates a serious impediment in building up a relationship between the two "allies". Suspicions about U.S. boots on the ground in Pakistan and subsequent delays in visas for aid-related personnel add to the discomfort. Chances of serious miscalculations are still strong.

But all is not lost, if leaders in both the United States and Pakistan, and civil society in both countries better understand each other's concerns and intentions, and work together honestly and openly to resolve difficulties. If they do not, the loss of Afghanistan may be overshadowed by a Western break-up with Pakistan and that may well portend a collapse of the fledgling political system inside Pakistan. 


\section{The Wars Within Pakistan}

2009

was a key transitional year for Pakistan, a strategically important country of some 175 million imprisoned as much by its geography as by its checkered history of military and civilian autocracy and misrule. The weak civilian coalition that inherited General Pervez Musharraf's crumbling instruments of state was unprepared to rapidly restore participatory government. President Asif Ali Zardari of the Pakistan Peoples' Party (PPP) chose to hang on for more than two years to the extraordinary powers wrested by his predecessor from the Prime Minister and Parliament. In the tradition of Pakistani politics as family business, he took on the mantle of power in the name of his young son Bilawal, who was named co-chairman of the party. While publicly espousing support for civilian supremacy and democratic rule, he lost the support of the other major parties that had rallied around the Charter of Democracy that his late wife Benazir Bhutto had signed and supported fervently. This Charter was meant to remove all vestiges of autocratic rule and restore the constitution to its original form. The rift between the PPP and the Pakistan Muslim League of former Prime Minister Nawaz Sharif widened in 2009 but the latter did not press the government hard enough, fearing the return of the military if political chaos ensued. Sharif also seemed to be kept off balance by the good-cop/ bad-cop routine of Prime Minister Yousaf Raza Gilani and President Zardari. Zardari appeared to outsmart his political rivals while making alliances across the board to retain a hand in governing all four provinces, including the Punjab, Sharif's home turf. But his lack of public acceptance and dwindling popularity became a serious hindrance to his credibility and effectiveness as a national leader.

Meanwhile the internal security situation in Pakistan nosedived in the first half of 2009, with the earlier military gains in Swat against the militant allies of the Tehreek-e-Taliban of Pakistan (TTP) wiped out by government inaction and a desire on the part of the provincial leadership of the North West Frontier Province (NWFP) to avert confrontation and offer peace deals to the militants. The militants chose to target individual leaders of the Awami National Party. The Federally Administered Tribal Areas (FATA) remained largely outside Pakistan's polity and economy despite the promise of Prime Minister Yousaf Raza Gilani to integrate it into the rest of the country. FATA continued to be a hotbed for terrorism and insurgency. Early in 2009, with the army in barracks again, the militants began taking over large swathes of territory inside the NWFP, taking over Malakand and Swat, and administering harsh "justice" in the name of Islam. Their sadistic practices and targeting of political leaders led to an exodus of civil and political elites from the territory to the relative safety of Islamabad and Peshawar. Word of their perverted systems of "Islamic justice" penetrated into Pakistani society. Public outrage reached a crescendo when a bootleg video of a teenage girl being whipped was captured on a cell phone and spread in viral fashion. The resulting public anger produced by that grainy image and the cries of the helpless girl being held down by bearded thugs turned the tide of Pakistani public opinion and re-energized the military. Suddenly the government in Islamabad realized that it had to get ahead of public opinion or lose its trust completely. The TTP's local allies meanwhile extended their reach beyond Swat into Shangla and Buner, abutting the strategic Karakoram Highway that links Pakistan to China and the motorway that links Peshawar to Islamabad. The dagger of militancy was pointed into the heart of Pakistan, just 70 miles from the capital. This galvanized the media and the Pakistan's public into action and got the attention of the West. The Pakistan army that had seen its public opinion ratings slip suddenly saw an opportunity to go back on the offensive against an enemy that it recognized as posing an "existential threat" to Pakistan, even more immediate than the historical danger from India to its east.

In 2008, military action in Swat had involved just one division of the Pakistan army. Now, some 54,000 troops moved into Swat. A complete division of troops, enhanced by three brigades cannibalized from the forces facing India, plus one commando brigade in the Peochar Valley headquarters of the militancy, took northern Swat. Another division plus two additional brigades, again borrowed from forces normally deployed against India, moved into the southern part of Swat, including Buner and Shangla. In addition two wings or regiments of the Frontier Corps from the FATA lent heft to the campaign. The TTP and its allies, 
the Tehreek-e-Nifaz-e-Shariat-e-Mohammedi (TNSM) were rousted from the region in short order but not before some 2 million internally displaced person were evicted to bordering areas of the NWFP and Punjab to allow the army to carry out a full scale invasion of the occupied territory. The departure of the civilians lessened the possibility of collateral damage and allowed the Pakistan Air Force to collaborate with the army in conducting a week long aerial attack on suspected militant positions, thus preparing for the ground assault. A Special Support Group organized under military officers was set up to help the refugees, yet only some 200,000 were given shelter in official camps. The rest were taken care of by Pakistani society and the Pakistani diaspora, exhibiting their resiliency and largeheartedness through their private efforts to provide food and shelter and even education, through the setting-up of temporary school systems.

Notably absent was NATO, which had played a major role alongside U.S. and Pakistani troops in the aftermath of the 2005 earthquake in the mountainous area adjoining Swat. This time, NATO had no rapid deployment force to offer aid. The U.S. had no helicopters to spare. And even if it did, the Pakistanis were reluctant to allow a U.S. footprint. U.S. President Obama's Special Representative Richard Holbrooke became the compassionate face of the United States, visiting refugees in the camps even before Pakistani leaders, (albeit under controlled and highly secure conditions). Absent too was the Pakistani political elite in the days after the exodus out of Swat, except the army chief General Ashfaq Parvez Kayani, who visited the area frequently. The disconnect between the political leadership and the masses was magnified, as the state failed to protect its people, pushing the army into the forefront yet again. Within six months, Swat was cleared of the militants and the refugees began returning home. But the civilian half of the partnership was not totally prepared to hold and protect the gains.

On the western front, facing a difficult and deteriorating situation in Afghanistan, the United States ratcheted up its drone attacks in the FATA, targeting not only Al Qaeda but also TTP figures, culminating in the death of Baitullah Mehsud, the founder of the TTP. "In the face of the intense Pakistani opposition to American boots on the ground, the Bush administration chose to rely on drones to target suspected militants. Bush ordered the CIA to expand its attacks with Predator and Reaper drones, and, according to a former Bush administration official familiar with the program, the U.S. government stopped notifying Pakistani officials when strikes were imminent or obtaining their "concurrence" for the attacks. As a result, the time that it took for a target to be identified and engaged dropped from many hours to 45 minutes."

The Obama Administration took the drone attacks to new heights, increasing them from five in 2007 and thirty-six in 2008, under the previous administration, to eightythree in 2009. In the first few weeks of 2010, there were a dozen drone strikes. ${ }^{3}$ These attacks - while tactically very effective - created a political backlash in Pakistan's hinterland. The attacks on Pakistani Taliban targets in the border region were meant to assuage Pakistani concerns about the invasion of Pakistani air space during this undeclared U.S. war on Pakistani territory. Mehsud had transformed the TTP from a tribal uprising in South Waziristan into a potent cartel that spread across the region and across tribal boundaries. His death threw the TTP into disarray and provoked a frenzy of attacks against soft targets in the hinterland, in Peshawar, Rawalpindi, and Lahore. The most spectacular attack was on the army headquarters in Rawalpindi. In the process, the TTP enlisted the support of some militant Jihadi groups from Central and Southern Punjab, an area that had provided recruits for the Pakistani state's support of the insurgency in Kashmir against India.

The reaction to the TTP attack from the army was the long planned attack on South Waziristan against the TTP's base and fixed assets. Following the pattern of the Swat operation, a one-week aerial assault against some 142 ground targets preceded the land attack by some 30,000 troops. Some of these forces were re-directed from Malakand and Swat. This much announced and highly integrated attack did not capture or kill the TTP leadership but dislocated the insurgency into neighboring territories in NWFP and North Waziristan, Orakzai, Mohmand, and even Khyber agencies. A backdoor into Wazir territory and from

\footnotetext{
2 Peter Bergen and Katherine Tiedemann, "The Drone War," The New Republic, June 3, 2009," http://www.newamerica.net/publications/ articles/2009/drone_war_13672.

3 Michael O'Hanlon and lan S. Livingston, "Pakistan Index: Tracking Variables of Reconstruction \& Security in Pakistan," Brookings Institution, February 10, 2010, http://www.brookings.edu/foreign-policy/pakistan-index. aspx.
} 
there into Afghanistan and North Waziristan allowed many militants to exit the Mehsud territory as the army closed in on them. The Pakistan army contended that coalition posts were evacuated on the Afghanistan border that might have hindered the escape of TTP militants. Subsequent military operations began in other agencies of FATA, and by Spring 2010, pockets of militants were identified and cordoned off in central and north western Orakzai and parts of the Tirah Valley of the Khyber Agency in what was described by Major General Tariq Khan, the Inspector General of the Frontier Corps as the "final battle". ${ }^{4}$ But absent a coordinated civil-military counter insurgency operation, and lacking sufficient U.S. weapons systems, helicopters, and COIN-specific aid, the army had to rely on its conventional force to fight a war against a shadowy and elusive force. Air force jets and artillery continued to be used where better equipped ground and heliborne attacks would have been more accurate and effective. The army and Frontier Force were attacking the symptoms, not the causes, of the disease of militancy that was attempting to penetrate the heart of Pakistani society.

\section{IIII. 2009: New Challenges}

M eanwhile, the United States, under a fresh and worldly President Barack Obama, sharpened its focus on the "necessary" war in Afghanistan, as it tried to make up for nearly a decade of neglect marked by billions of dollars of wastage. That the Afghan war could not be "won" without success in Pakistan became the frequently heard mantra of the new administration. Here, despite many steps forward, a strategy was slow to develop, and the distrust that the Atlantic Council warned of in 2009 remained, especially among the Pakistani people and the military. Today, without winning over the Pakistani army, a key player on the Pakistani political field, the U.S. faces the prospect of yet another estrangement in the bumpy fifty-six year-old U.S.-Pakistan alliance. Yet, this objective runs counter to its avowed goal of building up the civilian structures of government.

2009 had dawned with the dire prediction that the state of Pakistan could collapse within six months. ${ }^{5}$ Yet the soothsayers failed to calculate the internal strengths of Pakistani civil society, one that has learned to survive and even thrive in spite of a dysfunctional government. The long-gestating civil movement in support of the judiciary that helped bring down the Potemkin village edifice of the Musharraf regime was picked up by Nawaz Sharif as the vehicle for his own protest. His threat of a Long March on Islamabad had the desired effect. A reluctant army chief,

4 Conversation with author, April 8, 2010

5 David Kilcullen, interview by Carlos Lozada, The Washington Post, March 22, 2009, http://www.washingtonpost.com/wp-dyn/content/ article/2009/03/19/AR2009031903 038.html.
General Ashfaq Parvez Kayani, entered the fray behind the scenes. The PPP government relented and restored the Chief Justice of the Supreme Court Iftikhar Muhammad Chaudhry. Sharif called off the protest, reportedly after a message from the army chief guaranteeing the restoration, which was conveyed to him by Aitzaz Ahsan, the PPP lawyer who had been in the forefront of the lawyers' movement against Musharraf. A bloated government, with a reported eighty-three plus persons with the rank and privileges of minister, muddled through crisis after crisis.

On the external front, the attack on Mumbai by alleged members of the Lashkar-Taiba from Pakistani Punjab brought India and Pakistan on a collision course. But better sense prevailed on both sides. Indian Prime Minister Manmohan Singh, after his successful re-election, prevailed upon the hawks in India to hold their fire. Zardari, after initial missteps, including the offer to send his intelligence chief to New Delhi (without prior consultation with the military high command), persuaded the Prime Minister and the military to acknowledge Pakistani individuals' involvement in the attack. The government proceeded to charge seven suspects in connection with the Mumbai attack. But the government machinery was in disarray. The Prime Minister Yousaf Raza Gilani fired his National Security Advisor, retired Major General Mahmud Ali Durrani, after Durrani confirmed publicly to Indian media that the surviving member of the team that attacked Mumbai was from Pakistan. Durrani had been briefed on this fact by his contacts in the Pakistani intelligence 
establishment, specifically the ISI. The removal of the national security advisor also put an end the fledgling National Security Council apparatus that he was putting in place to assist the government in making defenseted decisions.

Ironically, the act of asserting civilian control over the military or military-related officials ended up weakening the government's ability to assess and act on defense-related issues: there was no secretariat for providing analyses or support to the civilian government. The Ministry of
Defence was populated by retired military officers. There was no expertise evident among the civilians to prepare for meetings of the Defence Committee of the Cabinet, for example. Zardari had failed to win over the confidence of the military, especially in the face of suspicions that he was too willing to appease and second-guess the United States and was going outside the agreed positions of the military on Afghanistan and India, two policy areas where the military continues to play a major role since the 1970 s.

\section{Moves Towards Democracy}

P akistan moved toward a democratic system with counter balancing arms of government with the restoration, after much foot dragging by the government, of the Chief Justice of the Supreme Court. Chief Justice Iftikhar Mohammed Chaudhry began asserting the role of the Supreme Court in key areas of governance. In the 1990s, Pakistan had a Troika: the President, Prime Minister, and the army chief. Now it appeared a new Troika seemed to be emerging: the President, the Army Chief, and the Chief Justice. The Supreme Court quickly nullified Musharraf's National Reconciliation Ordinance that essentially gave amnesty to all politicians charged with criminal offenses and permitted, among others, the return to Pakistan of the leaders of the Pakistan Peoples' Party and the Pakistan Muslim league (Nawaz group). The aftereffects of this decision are still reverberating in the corridors of power in Islamabad. The news media also appeared to become a major fourth-leg of the stool, although the noise from the 60 plus broadcast channels sometimes produced more confusion than clarity. Pressure on the President also led him to cede chairmanship of the National Command Authority that manages Pakistan's nuclear weapons to the Prime Minister. But he continued to resist changing the $17^{\text {th }}$ Amendment of the Constitution that had allowed General Musharraf to acquire extraordinary powers by wresting them away from the Parliament and the Prime Minister.
After much pressure from all sides, the PPP-led government succeeded in meeting its promise to the people and presented and parliament passed the $18^{\text {th }}$ Amendment to the constitution that did away with most of the egregious changes that Musharraf had made in the document. President Zardari signed the amendment into law on April 19, 2010. But this was not a restoration of the 1973 constitution. Some changes allowed the government to whitewash many tainted bureaucrats and politicians inside and outside the government and removed the bar of two-terms for the prime ministership and chief ministries of the provinces. A decades-old anomaly also changed the name of the North-West Frontier Province to Khyber Pakhtunkhwa but opened up debate and protests aimed at creating other language-based provinces. 


\section{Fragile Economy}

$\mathrm{n}$ the economic front in Pakistan, the momentum for change had been lost after the elections of 2008 , when the coalition collapsed and the Muslim League (N)'s Finance Minister, Ishaq Dar, and other ministers quit. A former Citibank executive with extensive banking experience in Pakistan, Shaukat Tarin, was appointed advisor for finance but lacked the political power to effect change. In 2009, finally, he was elected to the Senate and became a full-fledged minister and began taking steps to improve economic decision making.

A major move forward was the conclusion, after seventeen years of debate, of the National Finance Commission Award that re-ordered the revenue sharing relationships between the provinces and the center, turning back to the federal model that was intended in Pakistan's constitution. Implementation of this award is now in the hands of the authorities and the provinces. The transition is fraught since the provinces are not equipped to handle many of their new financial and fiscal responsibilities. And the government may have miscalculated the resource requirements of the transition, including raising expectations among the provinces of resource flows from the Center that may not be possible at this time.

With the failure of the newly-formed Friends of Democratic Pakistan to provide much needed aid, Pakistan's relations with the international financial institutions, especially the International Monetary Fund, with its strict financial and fiscal controls, returned to a semblance of normalcy. Musharraf's Prime Minister and Finance Minister Shaukat Aziz had stated that Pakistan had broken the "begging bowl" and would not resort to IMF financing. Now it became a necessity, as Tarin began the politically difficult process of changing the domestic economic scene. He revived the idea of tax reform and an improved tax administration, facing a buzz saw of opposition from the politicos in the process. A nation-wide Value Added Tax system was brought back to the drawing board. Remittances from overseas Pakistanis, especially from the Gulf, rose unexpectedly, even as global economies began to shrink. In 2009, some $\$ 8.8$ billion were remitted by Pakistani workers, far eclipsing any of the aid that Pakistan had been promised by its friends.

Despite the improving economic outlook, on February 23, 2010, a frustrated Tarin resigned suddenly for both personal and professional reasons after a period of trying to fend off cronyism in the appointment of senior officials to run the economy. He left behind a system that still lacked the coordinated and focused effort to reorder the economy in the face of global challenges and the institutions that would allow Pakistan to diversify and rebuild its economy. The government did succeed in passing through to consumers many of the price increases on imported energy. The core inflation rate was kept in control and the current account balance showed signs of improvement. After some delay, an experienced economist and former minister, Abdul Hafeez Shaikh, was appointed as the Finance Minister. He faces an uphill task in finding resources to restart the economic engine, introduce meaningful tax reform, and win the confidence of domestic and overseas investors in a period of political turmoil.

The IMF-supported stabilization effort over the past year has been broadly on track (though important targets continue to be missed) and has entailed some tough decisions (facilitated largely by a strong Finance Minister). However, 2010 entails even harder choices because the economy needs to move from stabilization to growth. Pakistan needs to grow at $7-8 \%$ again rather than the current target of $3 \%$ to stay ahead of its population growth. Growth will come only if public resources increase (tax reform) and are better used (public enterprises currently lose $\$ 3$ billion a year; public spending has huge leakages and the circular debt of its public enterprises that have not been paid even by government agencies adds to the government's burden). The Federal Bureau of Revenue has failed to collect taxes; it failed to meet IMF revenue targets. Personal contacts rather than professionalisms have been the hallmark of appointments to many key economic posts. Moreover the issue of circular debt plagues public and semi-public enterprises, as their bills remain unpaid, often by government entities. The state has placed multibillion rupees in interest-free accounts with the 
National Bank of Pakistan. Recovering those monies could help it retire many of its debts. But the political clout gained from those deposits remains a major attraction for civilian government leaders.

Pakistan needs to move out of its old fossilized industries, like basic textiles, up the value chain and explore the possibility of becoming a manufacturing center for regional and global industries. One suggestion is to move into supplying auto parts for China, India, and the United States. And private investment also needs to increase, creating better infrastructure, security, and governance. Implementing this next stage of reforms needs a strong Finance Minister, who can master the brief and can fend off interests. Tarin's departure was a loss. The choice, after some delay, of an experienced economist and former minister, Abdul Hafeez Sheikh, may help it regain its composure, provided he is given room to operate autonomously and can build a strong team to help manage the economy.

The much publicized and promised aid from the United States and the Friends of Democratic Pakistan (FODP) group sputtered along. Of the $\$ 5.6$ billion of aid from the FODP promised at its Tokyo meeting in April 2009, only $\$ 725$ million had been actually disbursed by year's end. The major donors who delivered this aid were the Kingdom of Saudi Arabia (\$400 million) and the United States (\$325 million), with Turkey providing $\$ 10$ million. Notably absent from the roster of those who delivered cash assistance was the traditional Pakistani ally, China, where reportedly the level of confidence in the Zardari administration was at a low ebb. Earlier China had placed $\$ 500$ million with the State Bank of Pakistan to help Pakistan. But even at the inaugural meeting of the FODP in New York, presided by President Barack Obama of the United States, China only sent its UN representative. Even the Saudis were reported to be holding off on any further major assistance, despite President Zardari's frequent trips to the Kingdom. Pakistan had programmed the pledged flows from the FODP into its budget, as had the IMF, and had to resort to further deficit financing to meet its shortfalls.

In the United States, most of 2009 was spent by U.S. lawmakers in crafting the Kerry-Lugar Bill or the Enhanced Partnership Act (S.1707), which contained pointed references to civilian control of the military in Pakistan and U.S. access to individuals who may be involved in nuclear proliferation. Further, the possibility of sanctions was raised in the context of non-compliance with these and other issues. Congress was acting to safeguard its interests in ensuring the effective use of U.S. aid, but the bill did not contain any specific indicators of success for aid effectiveness or disbursal. Nor were any indicators agreed upon with Pakistan in advance. Indeed, adding to the Pakistani pushback on conditionality was the growing concern in Pakistan that a large portion of the promised aid would be absorbed by auditors and monitors of U.S. aid in Pakistan. The U.S. failed to challenge and erase these concerns effectively. The presence of so many Americans in Pakistan could potentially fuel anti-American sentiment among a public attuned to many conspiracy theories about U.S. attempts to locate and take over Pakistan's nuclear assets. The focus on what many Pakistanis considered a repeat of earlier U.S. attempts to "control" Pakistan and its military and the revived specter of sanctions created a popular protest in Pakistan. All this happened notwithstanding the U.S. plans to use Pakistani-based auditors to monitor aid usage and flows. 


\section{The View from Washington}

T he Obama Administration had begun its term by ordering a fresh review of the Afghanistan and

Pakistan situation. Rather, it ordered numerous reviews and then synthesized them into a single review by former national security senior staff member Bruce Riedel. Individual reviews were conducted by the Chairman of the Joint Chiefs of Staff, Admiral Michael Mullen, the Commander Centcom, General David Petraeus, and national security staff member Lieutenant General Douglas Lute. The President sought advice from Vice President Joseph Biden and Secretary of State Hilary Clinton, among others. The result was a validation and reassertion of the importance of Afghanistan in the battle against Al Qaeda, with a central role for Pakistan. A special representative for Afghanistan and Pakistan was named, bringing in Ambassador Richard Holbrooke into that challenging role.

But some missed opportunities and early missteps marked this appointment and hobbled the envoy's ability to produce the regional focus and consensus that was necessary to solve the Afghan puzzle. A separate White House representative was appointed for Iran, removing that key neighbor from the calculus. And, succumbing to pressure from India, another key regional player, that country was removed from the orbit of Ambassador Holbrooke's activity. Moreover, there was pushback in Pakistan, as Pakistani civil and military leaders resented being put at par with Afghanistan, a country that they regarded as weaker and heavily dependent on Pakistan for access to the world and for its economic and (now) military survival. On its part, Afghanistan had never recognized the Durand Line frontier between it and Pakistan, a frontier that most Afghans feel had been imposed by the British Empire on a relatively weaker Afghan ruler in 1893. The simmering hostility between these two neighbors made the job of a regional strategy even harder.

On the plus side, the former Biden-Lugar and now KerryLugar Bill (referred to earlier) had made its way through the U.S. Congress and promised to change the U.S.-Pakistan relationship by moving to a longer-term commitment to Pakistan as a whole. This gave Ambassador Holbrooke a useful tool to break down the resistance inside
Pakistan. But he faced a serious challenge inside his own bureaucracy. Ambassador Holbrooke attempted to identify key sectors of the economy that needed immediate help. He focused on energy and infrastructure and also took upon himself to alter the Washington culture of aid by attempting to reduce the role of large U.S.-based contracting firms that captured much of the aid flows. And he managed to cancel some ill-defined projects that dealt with social sector engineering. Inside Pakistan, he attempted to work with the government but also to bring in public-private partnerships and non-governmental actors to make the aid more effective and to reduce leakage in the aid pipeline. In effect, he took on the entrenched interests and bureaucracies at home and in Pakistan. But his effectiveness was hampered by the continuing tension between the civil and military in Pakistan and the conflict between the military and political objectives of the United States for Pakistan.

The U.S. development assistance system had been reduced to a skeleton, with fewer staff, largely managing the outsourcing of contracts of major development contractors in the United States. The U.S. Agency for International Development staff had little presence or influence on the ground. It had shut down its office in Pakistan in the early 1990 s and in the process lost its expertise and ties to local individuals and institutions at the center and in the provinces. Moreover, different U.S. agencies operated independently of each other. Ambassador Holbrooke began assembling a team from across the government not only to create a critical mass of experience and knowledge but also to help break down the stovepipes that characterized Washington decisionmaking on Afghanistan and Pakistan. But he had to rely for resources on individual agencies and the bottlenecks inside the bureaucracies remained a major hindrance to rapid action. Yet, his team managed to infiltrate the sclerotic systems of the aid bureaucracy and launch a number of projects in Afghanistan and Pakistan. But internal tensions and frictions between his operation and other elements of the U.S. government remained. 
By the time he issued a year-end report in January 2010 , a number of key initiatives had been launched in both Afghanistan and Pakistan but the regional aspect of that promised strategy was still largely missing. As the point person for the administration in its interactions with legislators in congress, Ambassador Holbrooke made frequent attempts to convince congress to aim for a broader and deeper involvement in both countries' development efforts. There was surprisingly broadbased and bi-partisan support initially for an effort to help Pakistan, led by Senators John Kerry and Richard Lugar on one side of congress and Congressman Howard Berman on the other. Even President Obama mentioned a few times that he had been co-sponsor of the original BidenLugar bill and that it ought to have properly been named the Biden-Lugar-Obama bill!

However, progress on the aid bill for Pakistan was slow. Faced with a huge financial crisis at home and fearing the wrath of their constituents, individual Members of Congress from the House and Senate chose to overload the draft bill with a slew of "principles" and conditions that changed the tenor of the legislation from one of help to one of control, particularly in Pakistani eyes. Moreover, a domestic tussle was developing inside Pakistan, between the civilian government and the military on the execution of the war against the internal insurgency and militancy and the relationship with the United States. The United States, including Ambassador Holbrooke also had to contend inside Pakistan with a powerful military leadership that was sensitive to any public criticisms of its role, past or present. The Kerry-Lugar bill brought the military's concerns to the fore, seeming to pitch it against the civilian government. U.S Congressional staffers maintained that they had briefed senior Pakistani officials, including the army chief, about the bill at its earlier stages and had not received any negative feedback. However, once the Kerry-Lugar Bill was passed and landed on President Obama's desk, the Pakistan military publicly released its reservations about the bill but left it to the civilian government to handle the matter with the United States. The army let it be known privately that it had shared these reservations with the Pakistani government much earlier and expected that they would be shared with the U.S. authorities. Apparently, this was not done. Hence the public reservations and rebuke which gave fodder to numerous anti-US elements in Pakistan's polity, including the Islamist parties, to criticize the US-Pakistan alliance with rallies in the major cities and an active media campaign. The well-intentioned Kerry-Lugar Bill, representing a bipartisan coalition of support for Pakistan, suddenly became an anti-Pakistan symbol, akin to the notorious Pressler Amendment of 1985. Despite the sting of Pakistani criticisms, the U.S. Congress agreed to authorize, but has not yet appropriated, aid for Pakistan, shifting the onus of aid utilization on to the Pakistan government.

Adding to the unhappiness of the Pakistani military was the increasing number of objections to the bills that Pakistan was presenting to the United States for reimbursement of its expenditures for the movement of forces into the frontier region and the prosecution of the war against the militants in the areas bordering Afghanistan. The U.S. officials cited privately the inclusion of some items, such as $\$ 25$ million for barbed wire in successive years. On their side the Pakistani military added to the bill many extraneous items to replace equipment that was not even used in the forward lines or the war effort but that they felt was necessary in the overall war effort. What appeared to have been forgotten was the fact that the Pakistan army did not have a sophisticated expenditure tracking system in place. These payments of roughly $\$ 1$ billion a year were paid out of the Coalition Support Fund. The Pakistanis, both civilians and military, maintained that the amount they were getting was far below the total costs to Pakistan of the internal war. By their calculations, the price tag of the effort since 2001 was $\$ 30$ to $\$ 40$ billion. Yet, even the $\$ 1$ billion annual amount had not reached the Pakistan military, with much of the transfers reportedly used by the Pakistan Ministry of Finance for budget support purposes. These conflicting perceptions further deepened the disconnect between these two "allies". By 2010 the arrears on the CSF account of the amount due to Pakistan was close to $\$ 2$ billion $^{6}$, according to Pakistani calculations. In February 2010, the United States paid \$349 million, part of the arrears for 2008 , but the 2009 bills remained unpaid with promises that the rest of the arrears would be cleared in May and June. ${ }^{7}$

$6 \quad$ K. Alan Kronstadt, "Direct Overt U.S. Aid and Military Reimbursements to Pakistan, FY2002-FY2011," Congressional Research Service, March 9, 2010, http://www.fas. org/sgp/crs/row/pakaid.pdf.

7 There was movement on this score in early May. 
Total U.S. overt security-related aid to Pakistan for the period FY 2002-2011 totaled only $\$ 4.4$ billion. The CSF transfers, not aid but reimbursements for Pakistani costs related to the war against the militants and in support of the Afghan campaign of the United States, totaled some $\$ 7.2$ billion. Meanwhile total economic assistance over this period amounted to $\$ 6$ billion. The overt aid, therefore, was no more than $\$ 10.4$ billion over nine years, when compared to some $\$ 30$ billion a year in Afghanistan. Even in the Pakistan military there were strong reservations about these paltry flows compared with the needs of Pakistan. On the U.S. side, suspicions about Pakistan's reluctance to move against the Afghan Taliban remained rampant. Even while the U.S. military leadership worked hard to develop strong personal relations with the Pakistani military higher command, lower down the ranks in Pakistan doubts remained about U.S. commitment to Pakistan and the region.

Rather surprisingly, no one in Pakistan or the United States spoke of replacing the CSF with a military aid program based on mutually agreed performance targets and milestones. The CSF that General Musharraf had agreed to in a hurry essentially made the Pakistan army a force "on hire" to meet U.S. needs in Afghanistan and every year the reimbursement system renewed the resentment of that status on the Pakistani side. A key point of dispute was the lack of Pakistani operations against the so-called Afghan Taliban led by Mullah Omar, Jalalauddin Haqqani, and Gulbuddin Hekmatyar. Pakistan moved comprehensively against the local Taliban alliance but drew the line there. Its military initially stated that it had neither the manpower nor the equipment to go after the Afghan Taliban. (Here, the facts on ground went against one of those positions: the army had substantial troops in both South and North Waziristan but appeared reluctant to launch a Swat-type of operation that would create more IDPs. Instead, cordonand-search operations were possible and began on a small scale in recent weeks. It still lacked the equipment, such as helicopters, advanced jammers, more night vision devices, etc.) Moreover the Afghan Taliban had studiously avoided getting into a conflict against the Pakistan army. Meanwhile the view grew stronger in the United States that the Pakistanis were actively involved with the Afghan Taliban and were providing support for their operations in Afghanistan. Clearly, there was a wide gap between the two "allies". "Many people here feel Pakistan and the U.S. cannot be strategic partners, that this is only a marriage of convenience. They are in the same bed but they have different dreams," said Rifaat Hussain, a professor of defense and security studies at Quaid-i-Azam University in Islamabad, who was previously posted at the Embassy of Pakistan in Washington, DC. ${ }^{8}$

Exacerbating the disconnect was the growing number of drone attacks by the United States inside Pakistani territory. Sheltering under the much-debated premise that the Federally Administered Tribal Areas were "ungoverned territory", the U.S. Central Intelligence Agency and the military employed more and more drones in targeted attacks on Taliban and AI Qaeda targets. In its first six months in office the Obama administration launched more drone attacks inside Pakistan than the Bush Administration had in all of 2008. ${ }^{9}$ The Government of Pakistan continued to publicly protest against these strikes and sought greater control over the drone flights and their targeting. But reports emerged of surreptitious assistance from Pakistan in the form of airfields and logistical support for Predator drones to operate from Pakistan airfields near the Afghan frontier. The success of drone attacks inside FATA also pointed to the improvement of intelligence about potential targets, intelligence that could only be provided by Pakistani sources. The effect of this public criticism of drone attacks by the government further strengthened public antipathy against the United States in Pakistan's hinterland, even while the U.S. was attempting to rebuild its relationship with the Pakistani people.

\footnotetext{
8 Pamela Constable, "Pakistani Government, Military Wary of U.S. Overtures," The Washington Post, January 25, 2010, http://www. washingtonpost.com/wpyn/content/article/2010/01/24/AR2010012402890.html

9 Alexander Mayer and Bill Roggio, "U.S. Predator Strikes in Pakistan: Observations," The Long War Journal, July 21, 2009, http://www. longwarjournal. org/archives/2009/07/us_predator_strikes_3.php.
} 


\section{Hilistorical Mistrust}

$\mathrm{n}$ the Pakistani political narrative, history matters. Both its people and its government have long memories of their roller coaster relationship with the United States. In their narrative, the United States engages with Pakistan when it suits its global or regional interests and then departs. Spikes in the friendship, accompanied by military and economic assistance, occurred in the early 1950s to 1965 when a military alliance (ostensibly to fight the Soviets) ended with the Indo-Pakistan war and the stoppage of U.S. aid to Pakistan and India both. This left Pakistan vulnerable since it had become dependent on U.S. assistance. A long period of cool relations ensued till the Soviet Invasion of Afghanistan in December 1979. Pakistan suddenly became a frontline state willing to commit to battle against the Soviets. Aid started flowing again, even as the United States turned a blind eye to Pakistan's nuclear ambitions. And then another abrupt change followed. No sooner had the Soviet $40^{\text {th }}$ Army withdrawn from Afghanistan in 1989 than the United States departed the region, leaving Pakistan to deal with the influx of 3.5 million Afghan refugees, an army of Arab jihadi warriors, a "Kalashnikov Culture", and rampant drug addiction. Adding to the pain was the imposition of sanctions on Pakistan for its nuclear program and the threat of being declared a terrorist state for its support of the insurgency in Indian-held Kashmir.

The terrorist attacks on the United States of September 2001 revived the US-Pakistan alliance, with the U.S. needing Pakistan's strategic location and support to invade Afghanistan and upend the Taliban government in an attempt to get to the Al Qaeda leadership that had found refuge in that country. Suddenly aid began flowing to Pakistan again, peaking in 2009. The spikes in U.S. aid occurred during a period of military or quasi-military rule in Pakistan. Sanctions were imposed during civilian rule. Throughout, the U.S. view of the relationship was that Pakistan was a deceptive ally. But so long as there were no viable alternatives to supplying the war in Afghanistan, it was a necessary ally. For Pakistan, U.S. assistance again provided it the wherewithal to recharge its own military machine to prepare for a confrontation with arch-rival India. Paradoxically, the United States for the first time ever had a strategic partnership with both India and Pakistan, supplanting the former Soviet Union and then Russia as India's major partner. But an unintended consequence of the U.S. invasion of Afghanistan and the movement of the Pakistan army into the Federally Administered Tribal Areas (FATA) abutting Afghanistan was the rise of a militant Pakhtun insurgency that took the battle into the Pakistani hinterland. Suddenly Pakistan faced huge social and economic costs as well as a threat to the existence of the State.

Pakistan's government and population also recognized under the Bush Administration that the United States sought a long-term relationship with India on the basis of economic and political interests. In pursuit of that aim, the United States essentially pushed aside the Nuclear Non-Proliferation Treaty agenda and offered India a civil nuclear deal while ignoring Pakistan. The memory of the proliferation activities of Pakistani Dr. A.Q. Khan's remained fresh in U.S. minds despite the new military and civil relationship with Pakistan. On the Pakistani side, the fragility of the military-to-military relationship with the United States remained a live memory, especially for the new military leadership that had had its formative years during the period of the Soviet Afghan War and then suffered from the sanctions that followed the end of that engagement. 
T he historical memories that fed the mutual distrust between the United States and Pakistan pushed into the background the reality of their common interests and shared aims on four key topics:

\section{- Non-proliferation and protection of nuclear assets:} both the United States and Pakistan understood the dangers of proliferation of nuclear technology and weapons. Pakistan in fact benefited from U.S. assistance to train its military in protecting and safeguarding its nuclear assets. It would not be in Pakistan's interests to allow its knowledge or technology of nuclear weapons to leak onto the global marketplace, especially if it were to end up in the hands of nonstate actors.

- Strong economy: both the U.S. and Pakistan favored a strong economic base for Pakistan, given its enormous challenge of meeting the needs of a young population. With a median age of about eighteen years and a population of over 170 million, ${ }^{10}$ Pakistan faces huge challenges if it cannot expand the economy to educate, train, and give jobs to the "youth bulge" of its population. The counterfactual would be unimaginable, creating a huge recruitment pool of uneducated, unemployed youth for militancy and insurgency. The United States recognizes this challenge too, and has come up with a medium-term aid program to help Pakistan get back on the path of rapid economic development.

- Democracy: both the United States and Pakistan's political leaders, plus the new military leadership in Pakistan, recognize the importance of a stable and competent civilian government. After the long period of quasi-military rule under General Pervez Musharraf, the army leadership is of the view that its professionalism had been eroded. It needs to rebuild and reinvent itself. And it is willing to concede more space to the civilians to govern effectively. But a stunted civilian system that continues to be charged with corruption has been unable to gain the army's trust. It is in the interest of both the United States and Pakistan that Pakistan returns to a stable civilian rule.

10 Author's estimate
- Stable economic and political hub: Pakistan cannot escape its geography. It has a key location that can allow it to become a key hub of economic activity in South Asia, Afghanistan, Central Asia, Iran, and the Gulf. It could serve as a key transit point for energy and trade between South Asia and its western neighbors. And, it could provide the higher-skilled labor needed by the Gulf and Arabian Peninsula countries as they move from construction into services and manufacturing. Both the United States and Pakistan share this vision of Pakistan's future as a source of economic and political stability in the region.

Against this backdrop, the United States has also appeared to recognize the importance of a military-to-military relationship with Pakistan without diminishing the need to foster the growth of the civilian capability in Pakistan. Admiral Michael Mullen's laudatory piece on General Kayani in TIME magazine's special issue of 2009 was a reflection of this special relationship: "General Kayani, 57, commands an army with troops fighting in what President Barack Obama has rightly called the "most dangerous place in the world." He's lost more than 1,000 soldiers in that fight. He knows the stakes. He's got a plan." ${ }^{11}$ However, such public commentary sometimes serves to mislead the population in Pakistan into thinking that the U.S. has only short-term military relations in mind even at the expense of the longer-term development of the civilian system in Pakistan. And the constant stream of U.S. visitors, civil and military, to army headquarters strengthens the view inside the Pakistani military of its pre-eminent position in Pakistan's polity. The chances of miscalculation of its position vis-à-vis the United States by the Pakistan army are increased by this process.

The Pakistan army sees itself as indispensable to the internal stability of Pakistan and to the allied war effort in Afghanistan. Yet, it is wary of precipitate U.S. withdrawal from the region and the possibility that it would not be able to play a role in any resolution of the conflict inside Afghanistan. It also views its own military priorities

11 Admiral Mike Mullen, "The 2009 TIME 100 Most Influential People: Ashfaq Kayani," TIME Magazine, April 30, 2009, http://www.time.com/time/specials/ packages/article/0,28804,1894410_1893847_1894215,00.html. 
differently, with the first being the elimination of the military threat inside its own borders and concurrently to defend its eastern frontier. It also sees the U.S. military assistance as being slow and tight-fisted and likely will not undertake any massive new military operations to complement the U.S. surge in Afghanistan over the next year or so. It relies for leverage on the huge U.S. dependence on Pakistan as the supply route for the Afghan war. It wants and seeks U.S. aid to develop its own capabilities but not a strong U.S. physical presence, choosing to turn to other countries (e.g., Australia and United Kingdom) to train its troops in counterinsurgency warfare, for example. Yet, it is wary of over dependence on the United States and will hedge its bets in supporting U.S. actions whole hog in the Afghanistan Theater. The army has set up numerous training centers inside Pakistan to prepare for the Low Intensity Conflict that it faces and has revamped its training programs at the Pakistan Military Academy and other training institutions, while capturing the lessons of the fight against militancy through lectures and rewritten training pamphlets.

Externally, the army is now moving to a view of India as the less immediate threat and, as General Kayani described it, sees Afghanistan offering Pakistan a different kind of "strategic depth": through its stability rather than as a client state or a haven for Pakistani forces should India successfully invade Pakistan. "We want to have strategic depth in Afghanistan, but that does not imply controlling it," he said. "If we have a peaceful, stable and friendly Afghanistan, automatically we will have our strategic depth because our western border will be secure, and we will not be looking at two fronts."12 This is a major shift in strategic thinking inside army headquarters in Pakistan from a view that was born in the minds of is military leadership in the late 1980s and has continued to be cited erroneously as a core tenet of Pakistan's military strategy. Kayani has offered this view to NATO and to foreign and local journalists and opinion leaders. If this is more than just an exercise in diplomacy, it should lay the basis for a better

12 Pamela Constable, "Pakistan Army Chief Seeks Stable Afghanistan," The Washington Post, February 2, 2010, http://www.washingtonpost.com/wpdyn/content/article/2010/02/01/AR2010020102506.html understanding between the United States and Pakistan in years to come. He also went on record in supporting the need to "clear, hold, build, and transfer" territory taken from the insurgents. But the civilian components are still missing. It is critical for Pakistan and the United States both to ensure that the remainder of that equation is built up inside Pakistan and serious political and economic reform is undertaken to integrate the border regions into Pakistan proper.

Economic and political stability in the border region will allow Pakistan to concentrate on the need to put Pakistan on the path to steady economic development. U.S. aid will be a critical part of that effort but it will first have to leap the hurdle of public mistrust of the United States in Pakistan. An August 2009 Gallup Poll in Pakistan conducted for Al Jazeera network had 59 per cent of respondents seeing the U.S. as a bigger threat to Pakistan than India that came in at 18 per cent. ${ }^{13}$ This mirrors a Pew Poll of the U.S. public and members of the Council for Foreign Relations that indicated that only 16 per cent of American respondents had a positive view of Pakistan. ${ }^{14}$ And, the United States will need to find ways of creating Pakistani ownership of the aid program so that performance targets are set and reviews are conducted by Pakistani themselves, while both the U.S. aid machinery and Pakistani implementing agencies will need to ensure that aid reaches people on the ground rather than being diverted en route, as has been the case in the past. Good results on these fronts will help end the trust deficit between these two allies.

13 Al Jazeera-Gallup Pakistan Survey, "Pakistan: State of the Nation," Al Jazeera English, August 13, 2009, http://english.aljazeera.net/ focus/2009/08/2009 888238994769.html

14 "U.S. Seen as Less Important, China as More Powerful," The Pew Research Center for the People \& the Press, December 3, 2009, http:// people-press.org/report/569/ americas-place-in-the-world. 


\section{What Needed to be Done}

ast year, the Atlantic Council report on Pakistan, issued in February 2009 under the co-chairmanship of Senators John Kerry and Chuck Hagel, issued a clear warning captured in its title: "URGENT Needed: A Comprehensive U.S. Policy Toward Pakistan". One year into the Obama Administration the shape of such a policy is coming into focus but it has yet to take root. Not surprisingly, domestic political and economic considerations have diverted attention away from focusing on Pakistan to the extent that the country deserves. Not just the United States but also the international community has been tardy in meeting Pakistan's urgent needs. Domestically difficult policy actions have been left aside. Promised funds for the Friends of Democratic Pakistan have not been released. Military aid has been tediously slow in coming. And President Obama's statement of intent to withdraw from Afghanistan has been taken very seriously in Pakistan, reviving memories of the 1989/90 disappearing act of the United States from the region.

In 2009, we suggested the following main actions by the new U.S. Administration and this is how they turned out:

- A comprehensive and well funded policy within 90 days of taking office. A fresh "policy" (more a statement of intent) was announced in March 2009 but limited funding was available during the year to put it into effect.

- Making Pakistan the centerpiece of its own economic and political stability effort so it is not seen as imposed from outside. The US aid emphasis has been largely on Afghanistan though the rhetoric has favored Pakistan as the center of gravity of the situation. The Kerry-Lugar bill ended up emphasizing U.S. controls rather than involving Pakistan in setting performance indicators and taking ownership for effective use of aid. The IMF model of a Letter of Intent prepared for donors by the Pakistani authorities was not followed.

- The appointment of a special U.S. representative to work across the whole region. This was done, but Ambassador Holbrooke was not given the full regional authority that could have had greater impact.

- Rapid and substantial balance of payments (\$510 billion over two years) and budgetary support through international financial institutions and other donors, with better coordination between the U.S. Department of State and Treasury. The IMF came through with enhanced funding but the other donors have failed to deliver promised aid.

- Help build Pakistan's civilian institutions. No clear plan in effect as of yet in the United States and inside Pakistan.

- Use international and regional partners to reduce Indo-Pakistan tensions. Some progress evident in opening of talks between India and Pakistan. Greater U.S. behind-the-scenes efforts needed.

\section{- Increase capacity of Pakistan for COIN operations} and police. Pakistan has been given special funds for this purpose. Need to share with the public in Pakistan the nature of the Pakistan plans in this direction to dispel any notion that this is an intrusion into Pakistan by U.S. military or surrogates, such as Blackwater/Xe and the like. The Pakistan army has begun its transition to COIN but still lacks tools and large-scale U.S. aid to help it fight the war. It badly needs, among other things, helicopters and better jamming equipment to fight the militancy.

The heavy focus on the military effort without a commensurate civilian effort to change the economic and political landscape in the border region remains a cause of concern. Pakistan and the United States need to shift the focus from a short-term military solution to the transformation of Pakistan's polity and society into a democratic and egalitarian system, not one of political spoils and politics as family business.

- Support for targeted income programs to help the most disadvantaged of Pakistan's population. The Benazir Income Support Programme is underway but differences exist between the IMF and the World Bank on its efficacy and reach. There are fears that it will be used for partisan purposes.

- Open U.S. markets to Pakistani textiles. No progress on this front at all. The political will in the United States is missing for the "trade not aid" model that might win some Pakistani hearts and minds. But it must be understood that textile exports are not the panacea for Pakistan's economic ills. It needs to diversify its economy and move into manufacturing and value-added products. 


\section{Rapid Action Needed}

any detailed recommendations made by U.S. last year remain works in progress or just ideas on paper. These cover political and economic actions as well as support for the military. Lack of rapid action on these fronts will further strengthen the view inside Pakistan that the U.S. is not as serious about Pakistan's role and situation in the region as its leaders state it to be. The skeptics maintain that the United States has ulterior motives and only short-term interests. History, this say, will repeat itself. Domestic political events and the desire to build a partnership with India in South Asia will guide the U.S. actions in this regard, according to the critics.

How can the U.S. change this perception so it does not breed miscalculation by Pakistani leaders, civil and military nor create unrealistic expectations? The elevation of the discussion to a higher level under the rubric of the Strategic Dialogue between the United States and Pakistan in April 2010 with the promisee of more such exchanges in quick succession holds some promise. But the danger is that many of the efforts will be dissipated by focusing on too many objectives. Pakistan's needs are urgent on a few fronts. We, therefore, suggest some key areas for immediate action:

\section{- Increase Economic and Military Aid: Exceed}

Pakistan's expectations by offering it rapid economic and military aid but also bring it into the process of setting targets and performance in indicators, so the plans are made in Pakistan not in the USA. The shift in U.S. thinking appears to have begun now. Pakistan will need to show it can design and execute development projects speedily and effectively before patience among the donor community runs out. Signs that the U.S. recognizes Pakistan's needs for both conventional and COIN operations augur well for the future. But actions in support of those efforts with the provision of equipment and other resources will be more important than statements of intent.

- Provide Textile Industry Support: Increase Pakistan's market access to the United States by giving it lower tarrif rates, similar to those given to other trading partners. Pakistan's "high-tariff and apparel sectors... are taxed at an average of $11.4 \%$, nearly three times the average U.S. rate of $4 \%$ ". Pakistan accounts for only $3 \%$ of total U.S. exports in this sector and duty-free, quotafree access from all low income countries, including Pakistan, would only reduce U.S. textile production by less than one percent and apparel production by only $0.1 \% .{ }^{15}$

- Engage in a Civil Nuclear Deal: Begin discussions of a civilian nuclear agreement with Pakistan similar to one offered India in order to bring Pakistan into the safeguards regime of the International Atomic Energy Agency and by giving it ownership help prevent recurrence of proliferation activities. A civilian nuclear infrastructure designed to produce energy will give Pakistan the longer-term stability that it needs.

- Build Infrastructure/Create Jobs: Support the Special Representative's efforts to launch massive infrastructure projects to help Pakistan close its energy gap and build infrastructure that will knit the country together. Provision of electricity, for example, would allow the textile industry to double its employment from 1 to 2 million workers and to utilize its spare capacity. This will give Pakistan a breather as it retools its economy to move up the value chain. Inside FATA, a pool of some 300,000 male youth needs to be employed immediately in large-scale infrastructure projects. West-to-east roads, small dams, and construction projects based on the National Solidarity Program model of Afghanistan, with community involvement, and using the military's Frontier Works Organization as partners could begin this process. The army-led project to build roads in South Waziristan should be observed carefully to see how it can be owned and managed by the locals (along the lines of the National Solidarity Program in Afghanistan) and how Pakistani non-governmental organizations would be brought into the process to make effective and rapid use of such aid. Declaring an amnesty for owners of unregistered trucks in FATA would allow

15 Kimberly Ann Elliot, "Stimulating Pakistani Exports and Job Creation," Center for Global Development, April 15, 2010, http://www.cgdev.org/content/ publications/detail/1424056 
owners to operate them inside Pakistan proper and gain a livelihood from the growing demand for transport services in Pakistan.

- Signature Project: Another way of affecting longerterm public perception of U.S. actions in Pakistan may be the building of major rail and highway links between the port of Gwadar and the Afghan border in Balochistan and Khyber Pakhtunkhwa as a signature project. By employing Baloch labor for the segment operating in that province, it would help quell some of the discontent there with lack of economic opportunities for locals. And, apart from the economic benefits of better integrating the country's economic zones, such a major project would provide a lasting symbol of U.S. aid for Pakistan's development. Further, these links could eventually be extended into Afghanistan and Central Asia, providing a more efficient gateway for their economies.

- Create Performance Indicator System: The U.S. and other donors should assist Pakistan in setting up a central project monitoring and coordination operation in the Economic Affairs Division of the Government to coordinate the project plans of the provinces. This group should prepare project implementation timelines and performance indicators so Pakistan can take ownership for the implementation of aid projects rather than rely on armies of imported auditors and monitors. Further aid should then be contingent on effective use of prior aid flows. In effect, the role and functions of the Economic Affairs Division and the Planning Commission needs to be expanded and a well trained professional cadre of staff need to be in place to give greater confidence to donors that aid will be well used and audited. This may require moving away from the generalist civil servant running economic ministries in Pakistan today. Donors could insist on evidence of this shift in releasing new funds. It would be in Pakistan's interest to make aid use more effective and to have a permanent cadre of trained specialists handling such matters with external donors, making them immune to whimsical transfers and political pressures.

- Centers of Excellence: The United States can also make a lasting impression on Pakistani minds if it were to invest in a group of selected education institutions in different parts of the country as Centers of Excellence. It does not need to create new institutions as it had done in the Middle East with the American University model. But, it could help set up twinning arrangements between U.S. and Pakistani universities and provide direct aid to develop faculty and students and perhaps even lay the ground for exchange programs for both faculty and students. This generational investment would have far reaching results, giving Pakistan the boost it needs to develop local institutions and creating relationships with U.S. counterparts over time.

- Regional entente: The United States has a great opportunity as a strategic partner of both India and Pakistan to use its influence on both to bring them together to open up their borders to trade and to reduce the risk of hostilities. Despite India's reluctance to bring third party involvement in bilateral disputes, India and Pakistan have gained from such interventions in the past (the Soviet Union at Tashkent in 1965 and more recently, the U.S. after the attack on the Indian Parliament.) Reduction of military posture and threat, bringing their people closer by opening trade and tourism, and creating a South Asian economic zone that encompasses Central Asia would create the basis of sound economic and political development in both Pakistan and India. Political reluctance on both sides seems short-sighted and counter-productive to the aspirations of people of both countries. Active U.S. engagement could break that impasse. 


\section{Consequences of Inaction}

$f$ the United States walks away from Afghanistan

and Pakistan again, the hands of those extremists in

Pakistan that branded it as an untrustworthy ally will be strengthened. (The United States needs to show by its actions that it will not abandon the Afghan theater for a long time and will remain closely involved in Afghanistan's development.) Re-engagement will be harder the next time around. Pakistan also risks overestimating its leverage against the United States. As economic events at home and political crises elsewhere distract the U.S. government and shift attention away from Afghanistan and Pakistan, the latter may find itself struggling to get the economic aid that needs to jump start its economy. The United States still has a major hand in directing aid from multilateral aid agencies. Historically, the patterns of aid flows from the U.S. and the aid agencies and international financial agencies are congruent. Adding to the dangers is the continued reluctance of China and Saudi Arabia, two major Pakistani partners in the past, to commit large investments to Pakistan or to provide grants and other aid.
Pakistan's government must prove that it has the willingness and the ability to commit itself and its national resources to create a sustainable economic and political entity. Most of all, it must remain committed to providing good governance and security to its population so domestic investment resumes and foreign investment begins flowing again. Despite many difficulties and economic and political challenges, the civilian government has managed to produce consensus on constitutional changes and tried to meet the needs of the periphery by reducing the powers of the center. Agreement on the introduction of a nationwide Value Added Tax, revenue sharing under the NFC Award, and the repeal of the $17^{\text {th }}$ amendment and its replacement with the $18^{\text {th }}$ amendment are major steps in the right direction. The key now will be implementation of the ideas behind these changes. This is not a time for partisan political squabbles or brinkmanship. Otherwise, Pakistan may be pulled into a downward spiral and be left behind in a region that is witnessing rapid change and development. 


\section{The Atlantic Council's Board of Directors}

CHAIRMAN
${ }^{*}$ Chuck Hagel
CHAIRMAN,
INTERNATIONAL
ADVISORY BOARD
Brent Scowcroft
PRESIDENT AND CEO
*Frederick Kempe

\section{CHAIRMAN EMERITUS}

*Henry E. Catto

\section{VICE CHAIRS}

${ }^{*}$ Richard Edelman

*Brian C. McK. Henderson

${ }^{*}$ Franklin D. Kramer

${ }^{*}$ Richard L. Lawson

*Virginia A. Mulberger

*W. DeVier Pierson

\section{TREASURERS}

*Ronald M. Freeman

*John D. Macomber

\section{SECRETARY}

*Walter B. Slocombe

\section{DIRECTORS}

${ }^{*}$ Robert J. Abernethy

Timothy D. Adams

Carol C. Adelman

Michael A. Almond

*Michael Ansari

*David D. Aufhauser

Nancy Kassebaum Baker

Donald K. Bandler

Lisa B. Barry

Thomas L. Blair

Susan M. Blaustein

*Julia Chang Bloch

Harold Brown

Dan W. Burns

R. Nicholas Burns

${ }^{*}$ Richard R. Burt

Michael Calvey

Sarah C. Carey

Michael P.C. Carns

*Daniel W. Christman
Wesley K. Clark

Curtis M. Coward

John Craddock

${ }^{\star}$ Ralph D. Crosby, Jr.

Thomas M. Culligan

W. Bowman Cutter

Brian D. Dailey

Kenneth W. Dam

Robert E. Diamond, Jr.

Paula Dobriansky

Lacey Neuhaus Dorn

Conrado Dornier

Stanley Ebner

Eric S. Edelman

Thomas J. Edelman

Stuart E. Eizenstat

Robert F. Ellsworth

Julie Finley

Lawrence P. Fisher, II

Lucy Reilly Fitch

Barbara Hackman Franklin

*Chas W. Freeman

Carlton W. Fulford

Jacques S. Gansler

*Robert Gelbard

Richard L. Gelfond

*Edmund P. Giambastiani, Jr.

*Sherri W. Goodman

John A. Gordon

C. Boyden Gray

Marc Grossman

Stephen J. Hadley

Ian Hague

Harry Harding

Rita E. Hauser

Marten H.A. van Heuven

Richard C. Holbrooke

Mary L. Howell

Benjamin Huberman

${ }^{*}$ Robert E. Hunter

Robert L. Hutchings

Mansoor ljaz

William Inglee

Wolfgang Ischinger

Robert Jeffrey

*A. Elizabeth Jones
George A. Joulwan

Francis J. Kelly

L. Kevin Kelly

*James V. Kimsey

*Roger Kirk

Henry A. Kissinger

Philip Lader

Muslim Lakhani

Robert G. Liberatore

Henrik Liljegren

*Jan M. Lodal

Izzat Majeed

Wendy W. Makins

William E. Mayer

Barry R. McCaffrey

James P. McCarthy

Eric D.K. Melby

Jack N. Merritt

Franklin C. Miller

*Judith A. Miller

Alexander V. Mirtchev

${ }^{*}$ George E. Moose

William A. Nitze

Hilda Ochoa-Brillembourg

Philip A. Odeen

Ana Palacio

Torkel L. Patterson

William J. Perry

*Thomas R. Pickering

Andrew Prozes

Arnold L. Punaro

Joseph W. Ralston

Norman W. Ray

Teresa M. Ressel

Joseph E. Robert, Jr.

Jeffrey A. Rosen

Charles O. Rossotti

Stanley Roth

Michael L. Ryan

Marjorie M. Scardino

William O. Schmieder

John P. Schmitz

Jill A. Schuker

Matthew R. Simmons

Kiron K. Skinner

*Helmut Sonnenfeldt
Richard J.A. Steele

Philip Stephenson

*Paula Stern

John Studzinski

William H. Taft, IV

Peter J. Tanous

Peter Thomas

Paul Twomey

Henry G. Ulrich, III

Enzo Viscusi

Carl E. Vuono

Charles F. Wald

Jay Walker

Mark R. Warner

J. Robinson West

John C. Whitehead

David A. Wilson

Maciej Witucki

R. James Woolsey

Dov S. Zakheim

Anthony C. Zinni

HONORARY DIRECTORS

David C. Acheson

Madeleine K. Albright

James A. Baker, III

Frank C. Carlucci, III

Warren Christopher

Colin L. Powell

Condoleezza Rice

Edward L. Rowny

James R. Schlesinger

George P. Shultz

John Warner

William H. Webster

\section{LIFETIME DIRECTORS}

Lucy Wilson Benson

Daniel J. Callahan, III

Geraldine S. Kunstadter

Steven Muller

Stanley R. Resor

William Y. Smith

Ronald P. Verdicchio

Togo D. West, Jr.

${ }^{*}$ members of the Executive Committee as of May 132010 


\section{遗 ATLANTIC COUNCIL}

Atlantic Council

11th Floor, 1101 15th Street, N.W.

Washington, DC 20005

Address Services Requested 